\title{
The Way of Which Warriors? Bushidō \& the Samurai in Historical Perspective
}

\author{
$\operatorname{Karl}$ FRID $A Y^{*}$
}

\begin{abstract}
Modern commentators have too often attempted to treat bushidō as an enduring code of behaviour readily encapsulated in simplistic notions of honour, duty, and loyalty. The historical reality, however, is anything but simple. Samurai ethics and behavioural norms varied significantly from era to era-most especially across the transition from the medieval to early modern age- and in most cases bore scant resemblance to twentieth-century fantasies about samurai comportment.
\end{abstract}

Keywords: bushidō, samurai, honour, duty, loyalty, war stories

\section{Pot katerih bojevnikov? Bushidō in samuraji v zgodovinski perspektivi Izvleček}

Številni komentatorji so v modernem času pogosto obravnavali bushidō kot trajen kodeks obnašanja, ki ga je mogoče zlahka zaobjeti s poenostavljenimi pojmi, kakor so čast, dolžnost in zvestoba. Zgodovinska resničnost pa je vse prej kot preprosta. Samurajska etika in norme obnašanja so se močno razlikovale od obdobja do obdobja - še posebej na prehodu iz srednjeveškega v zgodnje moderno obdobje - in so v večini primerov le bežno spominjale na fantazije o samurajskem obnašanju, ki so se oblikovale v dvajsetem stoletju.

Ključne besede: bushidō, samuraji, čast, dolžnost, zvestoba, vojne pripovedi

On the fourteenth day of the third (lunar) month of 1701, Asano Naganori, the young and recently named daimyō of the Akō domain (in modern-day Hyōgo prefecture), was serving in the castle of the fifth Tokugawa shögun, Tsunayoshi. Engaged in arranging a reception for envoys from the imperial court, Naganori had somehow run afoul of Kira Yoshinaka, the ranking master of protocol assigned to instruct him, with the result that Yoshinaka had endeavoured to humiliate him publicly on several occasions. Naganori, who was apparently driven

Karl FRIDAY, Professor,

Graduate School of Humanities and Social Sciences, Saitama University,

Saitama, Japan

kfriday[at]mail.saitama-u.ac.jp

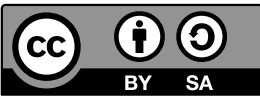


more by youthful righteous indignation than pragmatism and sound judgement, ambushed Yoshinaka in the halls of the castle, wounding him-albeit not fatally-with his short sword. Shogunal law on such matters was both clear and strict: drawing a weapon within the confines of the shogun's castle was a capital offense, whatever the motivation behind it. Accordingly, Naganori was ordered to commit seppuku (ritual suicide), and his domain was confiscated.

In the aftermath of this decision by the shogunate, retainers of the now-defunct Asano domain met to discuss their response. Led by the chief retainer, Öishi Kuranosuke Yoshio, they devised a complex plan for revenge on Yoshinaka, whom they blamed for their master's demise. In order to allay the suspicions of either the Kira house or the shogunate (who would naturally have been expecting a vendetta), the Akō warriors agreed to scatter and lay low for some time, reassembling nearly two years later, after Yoshinaka had long since relaxed his guard.

On the fourteenth night of the twelfth month of 1702, they struck. Fortyseven former Asano retainers attacked and killed Yoshinaka in his home in Edo, delivered his head to Naganori's grave, and then surrendered themselves to shogunal authorities for judgement. After a lengthy debate, they were ordered to commit suicide.

The story of the 47 Ako rōnin ranks among the best-known, and best-loved tales about the samurai. But while the ronin have long been popularly acclaimed as the ultimate examples of samurai loyalty and honour, the events and the actions of the principals were actually much more controversial at the time than most people realise. Far from representing a straightforward, edifying account of samurai virtue, therefore, the Akō Incident actually illustrates the complexity of samurai thought, and early modern ideals concerning honour and loyalty.

The shogunate's decision notwithstanding, public sentiment at the time and since has come down heavily on the side of the ronin. The story was fictionalised into a stage drama (Chüshingura, or A Treasury of Loyal Retainers) and subsequently served as the plot of a half-dozen or more movies. In like manner, the militarists of the early twentieth century saw the Asano retainers as the very embodiment of samurai virtue.

But evaluations of the incident varied widely among the early eighteenth-century "authorities" on proper samurai comportment. There was, to begin with, a great deal of debate within the shogunate itself. Ogyū Sorai, Dazai Shundai and several others censured the rōnin for placing their personal feelings above their higher duty to uphold shogunal law and protect the public order. In contrast, Hayashi Nobukatsu, Miyake Kanran, among others, praised them for their purity of 
motive and the selfless nobility of their actions. ${ }^{1}$ But perhaps the most significant condemnation of all came from Yamamoto Jōchō, the author of Hagakure, which ranks among the two or three best-known and most celebrated expositions of Tokugawa period bushidō. Jōchō judged the rōnin to have been too calculating and rational, and was particularly bothered by their decision to wait to carry out their vendetta, stating that they should instead have rushed to attack Yoshinaka immediately, without concern for the outcome:

What if [their intended victim] Lord Kira had died of illness in the interim? It would have been a terrible shame. Warriors of the Kamigata region are clever and shrewd in finding ways of being showered in praise $[. .$.$] they are unable to override the shackles of rational judgement.$ (Yamamoto 2014, 70-71)

All of this points to an important truth: While both scholarly and popular accounts of samurai ethics and values frequently presume or imply the existence of a relatively unified and well-defined code guiding warrior behaviour throughout samurai history and beyond, this notion is terribly misleading. The function of warriors, their place in Japanese society, and the purpose and conduct of war evolved and changed many times over the nearly millennium-long epoch between the birth of the samurai and their abolition in the late nineteenth century, giving rise to substantially different visions of proper warrior behaviour from one era to the next. Moreover, ideas about samurai values have been reshaped multiple times during the modern era. ${ }^{2}$ The "way of the samurai" is not one construct, but many.

The difficulties involved in elucidating the essence of "bushidö" begin with the term itself. Scarcely used at all before modern times, the word was so unusual that Nitobe Inazō, whose 1899 tract, Bushido: The Soul of Japan, probably did more than any other single book to popularise the trope in both Japan and the West, was able to believe that he had invented it himself (Hurst 1990, 512-3; Nitobe 1969).

Even as a kind of historiographic term - a modern label for warrior ideologybushido is a problematic construct, one that has long provoked much pontification but very little agreement concerning substance. In practical terms, bushi$d \bar{o}$ is perhaps best understood as belonging to the same class of words as terms like "patriotism", "masculinity", or "femininity". That is, most people allow that

1 A complete translation of the shogunate's debates appears in Hiroaki Sato's Legends of the Samurai (1995, 304-38).

2 For details, see Benesch 2014. 
these are desirable qualities to manifest, but few agree on what they actually involve: Are Edward Snowden or Daniel Ellsberg true patriots, or does that label more appropriately fit Oliver North or Geert Wilders? Is Angela Merkel more or less feminine than Marilyn Monroe?

There was, in fact, very little written discussion of proper warrior behaviour prior to the seventeenth and eighteenth centuries, marking the concept of a code of conduct for the samurai as a product of the early modern Pax Tokugawa, not the medieval "Age of the Country at War". The significance of this timing cannot be over-estimated, for the early modern era was marked by two dramatic changes to the lives of warriors - in addition to the end of the fighting that had hitherto been the defining feature of their existence.

First, the samurai became-for the first time in their history-a legally-defined social order. That is, warriors were transformed from an occupational group demarcated mainly by possession of certain skills to a socio-political class in which membership was almost purely hereditary. And second, warriors were moved off the land. This process began in the waning decades of the medieval epoch, as daimyo experimented with ways to make their armies more efficient and their retainers less independent, and continued through the early 1600s. By the midseventeenth century, most samurai were living in castle towns, subsisting on stipends from their overlords (rather than rents and taxes from villages they controlled in the manner of their medieval forebears). By 1700, more than 90 percent of the samurai were living in this manner.

These developments radically altered the relationship between lord and vassal. Obligations that until then had been reciprocal became one-sided, and characterised by vassal dependence. The bonds also became less personal, directed toward the position of the domain lord, rather than to the man himself. Daimyo rapidly came to be seen not as warlords who attracted and held followers by means of personal qualities and achievements, but as the titular heads of the bureaucratic organisations in which retainers were now employed. Loyalty became directed to the domain, as symbolised by the daimyo, marking the beginnings of something more akin to modern patriotism than to traditional feudal loyalty.

Under these conditions, ideas about warrior honour and behavioural norms became formalised and often quaint. The role of the warrior became a major philosophical problem for the samurai, inasmuch as they had stationed themselves at the top of the socio-political hierarchy, and yet had effectively lost their original function. Most samurai of this period were sword-bearing bureaucrats and administrators, descended from, but only nominally identifiable as, warriors. Accordingly, the motivation held in common by all those who wrote on the "way of 
the warrior" was a search for the proper role of a warrior order in a world without war. The ideas that developed out of this search owed very little to the behavioural norms of earlier times.

\section{Honour, Anachronism \& Ethnocentrism}

Honour is a knotty construct. While analogous concepts are widespread across time and space, "honour" represents a ubiquitous value only in the sense that a great many cultures entertain some sort of corresponding ideal. But the substance of honour-the specifics of what behaviours are and are not held to be "honourable"-are peculiar to individual times and places.

When we speak of "samurai honour", therefore, we must take care to define our terms - and our times. Indeed, even the terminology employed to label the construct of warrior honour varied across time, and multiple terms were often bandied about during a single age. The words foreign or modern observers have translated as "honour" include na (literally, "name"), menmoku ("face"), eiyō ("praiseworthy"), giri ("duty"), and a host of others, each slightly different in nuance and connotation.

Nevertheless, it is fair to say that throughout the classical, medieval and early modern epochs, honour and reputation lay at the heart of a warrior's self-perception, and provided the context within which warrior behaviour must be evaluated. A samurai's reputation, honour and pride were almost tangible entities that took precedent over all other obligations. As a thirteenth-century commentary enumerating the "seven virtues of a warrior" concludes, "to go forth to the field of battle and miss death by an inch; to leave behind one's name for myriad generations; all in all, this is the Way" (Kokon chomonjū 9.12.333).

Slights to reputation or honour were often catalysts to belligerence and bloodshed. Breaches of etiquette and failure to show proper respect could lead to violent consequences. Anecdotes in the twelfth-century didactic tale collection Konjaku monogatarish $\bar{u}$, for example, tell of a warrior who was shot for failing to dismount from his horse in the presence of a higher-ranked samurai, and of another samurai lord ordering the death of a warrior for being rude. Nihon kiryaku, a court-sponsored history, relates that in 989 two warriors in the capital got into a quarrel over drinks and "went to war", in the process shooting down several of the officers sent to quiet them (Konjaku monogatarish $\bar{u}, 25.4,25.10$; Nihon kiryaku, 989 11/23).

Azuma kagami, the first shogunate's didactic record of its own history, describes even more colourful incidents, such as one that began when Miura Yasumura 
and some of his relatives were having a drinking and dancing party in a "lascivious house" near Shimoge Bridge in Kamakura, while warriors of the Yūki, Oyama and Naganuma households were having a similar party near the other end of the bridge. At some point during the festivities, Yüki Tomomura took it into his head to practice long-distance archery, and began chasing and shooting at a dog outside the house. Unfortunately, one of his arrows went wild, and ended up in a screen in the house in which the Miura were gathered. Tomomura sent a servant to fetch the arrow back, but Yasumura refused to give it to him, berating Tomomura for his rudeness. An argument quickly ensued, and before long both sides had assembled mounted troops and launched a full-scale battle (Azuma kagami, 1241/11/29).

Malicious gossip carried between warriors by third parties could also prompt samurai to take to the saddle. ${ }^{3}$ The seriousness with which gossip and personal insults were taken is reflected in the language of shogunal laws:

Battle and killing often arise from a base of insults and bad-mouthing of others. In momentous cases the perpetrator shall be punished by exile; in lighter cases, he shall be punished by confinement. If, in the course of judicial proceedings, one party should bad-mouth the other, the dispute shall be settled in favour of his opponent. Further, if his argument is otherwise without merit, he shall have another of his holdings confiscated. If he has no holdings, he shall be punished by exile. (Goseibai shikimoku, 358-9)

Honour-or conversely, shame-could reach beyond the warrior himself, and even beyond his lifespan. Samurai could prosper through the inherited glory of their ancestors or suffer the stigma of their disgrace. Filial piety and familial honour were, in fact, often a cause of private warfare. ${ }^{4}$ Large-scale vendettas were surprisingly rare, but attempts to avenge slights against family members were common and troublesome enough to merit specific mention in Kamakura law:

Furthermore, in the case of a son or grandson who kills the enemy of his father or grandfather, said father or grandfather shall also be punished for the crime, even if he protests that he had no knowledge of it, because the father or grandfather's enmity was the motive that gave rise to the act. (Goseibai shikimoku, 358)

3 See, for example, Konjaku monogatarishū 23.13, 25.3, and 25.5.

4 See, for example, Suisaki 1079 8/30; Shōmonki (Hayashi 1975, 65); Mutsuwaki 23; Heian ibun doc. 2467; Konjaku monogatarishū 25.4, 25.9; Shōyūki 989 4/4; Azuma kagami 1219 1/27. 
Medieval warriors might also refuse orders from their superiors, risk the loss of valuable retainers, and even murder men to whom they owed their lives, all for the sake of their reputations. Even a warrior's life could be of less consequence to him than his name and image, and we find in accounts of early battles numerous sketches of warriors choosing to sacrifice themselves in order to enhance their reputations or those of their families. ${ }^{5}$

Be all that as it may, the key-and all-too-often-overlooked-point to be born in mind is that medieval samurai honour, early modern samurai honour, and modern ideas about samurai honour, were all distinctly different things. We must, therefore, resist anachronistic or ethnocentric assumptions about the nature of "honour", or about the sort of conduct it might be expected to have engendered.

For while honour and shame were central to samurai's self-perception throughout their history, in the premodern age, both turned on a warrior's military reputation, which turned first and foremost on his record of victories. Medieval Japanese concepts of honour and of honourable conduct in battle were flexible, and permitted successful warriors to rationalise a variety of behaviour that would have been met with considerable chagrin by Tokugawa-era bushido pundits or twentiethcentury proponents of "samurai values". While some aspects of medieval warrior ethics are very much in harmony with notions of honour, as modern (or Western) audiences understand this construct, others seem shockingly "dishonourable" by contemporary lights. For most of the first seven centuries of their existence, Japanese warriors were far more concerned with expediency, self-interest, and tactical, strategic or political advantage than abstractions. ${ }^{6}$

\section{Some War Stories}

One of the most famous stories about early samurai behaviour concerns a conflict between two tenth-century warriors, Minamoto Mitsuru and Taira Yoshifumi, recorded in Konjaku monogatarish $\bar{u} .^{7}$ In this account, gossip carried between the two ignites a quarrel, resulting in a challenge to combat. The two sides issue

5 See, for example, Konjaku monogatarishū 25.6, 29.5; Kokon chomonjū 9.13.347, 9.12.333; Mutsuwaki 23, 25-6; Azuma kagami 32-33; Azuma kagami 1180 8/26, 1184 4/21 1205 6/22, 1221 6/6 $124111 / 29$.

6 Matthew Strickland observes that, "despite drawing on established concepts, honour [is] ultimately a personal issue [...] governed by the conscience and self-esteem of the individual" (Strickland 1996, 125-31).

7 The tale appears in Konjaku monogatarish $\bar{u}, 25.3$. 
invitations to meet at a designated place on a specified day, and then set about putting their troops in order and preparing to fight:

On the agreed upon day, the two warbands set forth, coming to face one another across the designated field at the hour of the serpent. ${ }^{8}[\ldots]$ While all prepared their hearts, readying to cast aside their bodies and disregard their lives, they planted their shields in rows, facing one another at a distance of about one $c h \bar{o}^{-}$

Each side then sent forth a warrior to exchange written challenges. As those stalwarts returned to their ranks, there began, as was customary, a flurry of arrows. The warriors did not look back or even hurry their horses forward, but returned quietly - thus displaying their bravery. After this, both sides moved their shields closer together and were about to begin shooting, when Yoshifumi called to Mitsuru.

To simply set our respective troops discharging arrows at one another does not serve the interest of today's battle. Let only you and I learn of each other's skill. Instead of having our troops engage, how about if only the two of us ride at one another and take our best shots?

Mitsuru concurs and, after cautioning his men to stay out of the fight, even should he lose, rides out to engage Yoshifumi alone. The two make several passes at one another, but neither is able to land a decisive shot. At length they agree to call the matter a draw and, having settled their quarrel, spend the remainder of their lives amicably.

The behaviour of Mitsuru and Yoshifumi in this tale accords well with the received wisdom concerning classical samurai warfare, and is, in fact, the principal source cited in support of several key points thereof. But it contrasts vividly with another account, in the same text, about two later tenth-century warriors, Taira Koremochi and Fujiwara Morotō. ${ }^{10}$

As in the Mitsuru and Yoshifumi story, a dispute over a piece of land festers, fuelled by gossip, until at length a challenge is issued and date and place agreed upon. As the day of battle approaches, Morotō finds himself outnumbered nearly three to one and, apparently determining discretion to be the better part of valour, flees instead to a neighbouring province. The narrator of the tale informs us that "Those who spoke between the two warriors pronounced favourably on this."

8 9:00-11:00 AM.

9 One chō is approximately. 110 meters.

10 Recounted in Konjaku monogatarishū 25.5. 
Koremochi, upon receiving this news, determines things to be safe and demobilises his men, who have been pestering him to allow them to return to their homes. But shortly thereafter, Koremochi and his household are startled from their sleep by Morotō, approaching with a sizeable force. Morotō's men surround Koremochi's compound, set fire to the buildings, and shoot down anyone who emerges. When the fire has burned itself out they search the ashes, "discovering men of high and low rank, children and the like-all told more than eighty personsburned to death."

En route home, Morotō pauses near the home of his brother-in-law, Tachibana Yoshinori, to give his troops a rest, whereupon the men celebrate their victory by gorging themselves on food and sake, until they pass out. Unbeknownst to them, however, Koremochi is not dead. He had escaped by seizing a robe from one of his serving women, and slipping past the attackers under the cover of the smoke ${ }^{11}$

"Dropping into the depths of a stream to the west, he carefully approached a place far from the bank where reeds and such grew thickly, and clung there to the roots of a willow", hiding until the fighting was over and Morotōs troops had withdrawn. Some of his own troops who had not been in the house later find him, and re-supply him with clothing, weapons, and a horse, while he explains what had happened, adding that he had chosen not to flee into the mountains at the beginning of the attack because he feared that "this would have left behind the reputation of one who had run away." His men counsel him to wait and reassemble his forces before going after Morotō, whose troops still outnumber them five or six to one. But Koremochi shakes off this advice, arguing:

Had I been burned to death inside my house last night, would my life exist now? I escaped in this manner at great cost, yet I do not live. To show myself to you for even one day is extremely shameful. Therefore, I will not be stingy with this dew-like life. You may assemble an army and fight later. As for myself, I will go [on to attack] alone. [...] No doubt I will send off [only] a single arrow and then die, but to choose otherwise would be a limitless shame for my descendants. [...] Those of you who begrudge your lives need not come with me; I will go alone.

Koremochi and his men thereby fall upon Morotō's troops, taking them completely by surprise. Drunk and sated, Morotō's side is able to offer only a half-hearted defence, and is soon utterly destroyed. After taking Morotōs head, Koremochi moves on to his home, which he puts to the torch.

11 Azuma kagami 1184 4/21 recounts a similar incident involving a warrior escaping danger disguised as a woman, and even getting a friend to impersonate him and draw off pursuers. 
The protagonists' obsession with their reputations throughout this tale is noteworthy, but also complicated. The challenge to fight, the agreement on time and place, Koremochi's refusal to run away at the outset of Morotō's attack, and his speech to his men after they find him on the morning after all fit well with modern expectations of "honourable" samurai behaviour. But his method of escape from the burning house, his counter-attack, his gratuitous destruction of Morotō's home, Morotō's decision to run rather than face Koremochi at the agreed-upon time, and other incidents are a far cry from popular notions of samurai honour.

Moreover, in spite of very similar beginnings, the conflicts between Yoshifumi and Mitsuru, and between Morotō and Koremochi proceed in such stark contrast to one another that readers are left wondering if perhaps there could have been two competing warrior ethea during the tenth century. A second possibility is that confrontation between Yoshifumi and Mitsuru, which would had to have occurred about 150 years before the text that records it was compiled, may simply represent a kind of creative nostalgia — an idealised image — of earlier warriors on the part of twelfth-century litterateurs.

In any event, two points demand our attention here: First, there is no disregarding the fact that the tale was calculated to impress the very same audiences who regarded Koremochi as heroic. And second, Yoshifumi and Mitsuru's handling of their feud was clearly exceptional. In other sources, the aplomb with which the early samurai engaged in deceit and subterfuge is striking. The acceptance of both warrior and non-warrior audiences of this sort of behaviour is still more so.

Another incident related in the same text, for example, describes the tactics employed by Taira Sadamichi, a retainer of Minamoto Yorimitsu (944-1021), in hunting down another warrior (Konjaku monogatarishü 25.10). Commanded by Yorimitsu's illustrious younger brother, Yorinobu (968-1048), to take the head of a certain warrior from a nearby province, Sadamichi initially disregards the order, which was issued publicly, in the midst of a drunken party, and by Yorinobu, with whom Sadamichi had no prior relationship. But some three or four months later, having completely forgotten the whole affair, Sadamichi chances to meet the very man he had been ordered to kill.

The two ride along together, engaged in friendly conversation for some time, until the would-be victim, having heard the story of Yorinobu's order, asks Sadamichi about it. Suddenly recalling the incident, Sadamichi laughs and explains that he has chosen to ignore the command, which he believes to have been foolish and unreasonable. The other warrior relaxes, thanking Sadamichi 
for his generous attitude. He adds, however, a note of caution lest Sadamichi change his mind, warning him that he would not be an easy man to reckon with. This bit of arrogance induces Sadamichi to do exactly that. Quietly parting from the man, he rides out of sight to don his armour and prepare himself, only to return minutes later to catch his hapless victim riding along on a spare horse, unarmoured, and shoots him down before he can even reach his weapons.

In yet another tale from that text, a warrior slays the man who killed his father by disguising himself as a servant bearing food, sneaking into the man's room (while he rested in the home of the samurai's master), and slitting his throat as he slept. And Azuma kagami recounts how the first Kamakura shōgun, Minamoto Yoritomo, had one of his men executed for treason by summoning him to his quarters and entertaining him with food and drink, in the midst of which another of Yoritomo's men, Amano Tōkage, stepped forward with a sword to lop off the unfortunate man's head. In none of these accounts is there any suggestion that this sort of conduct is improper (Konjaku monogatarishū 25.4; Azuma kagami 1185 6/16).

The prominent role of deception, ambush and surprise attacks in these anecdotes seems discomfortingly unheroic to modern audiences. But such behaviour is, in fact, one of the enduring themes of Japan's martial legacy, and can be seen as far back as the Kojiki, in the exploits of Yamato Takeru no Mikoto, and at least as recently as the Pacific War.

Artifice and subterfuge in war are not, of course, by any means unique to Japan. Medieval European lords also happily built on tactics of betrayal and deception to secure victory. Matthew Strickland points, for example, to the 1118-1119 campaigns between Henry I and Louis VI, fought principally in Normandy, which demonstrated the repeated use of guile in almost every aspect of the fighting. And yet, argues Strickland, few of these acts provoked reproach from the pens of those who chronicled them. On the contrary, knights applauded cunning, guile and surprise, even in tournaments, and acknowledged them as fundamental and ubiquitous elements of war (Strickland 1996, 128-31).

Even so, the Japanese attitude toward this issue stands out. For in medieval Europe, betrayal and deception were restricted by conventions of war that sought to regulate fighting to the mutual benefit of both sides in any struggle. They were legitimate only because of legalistic loopholes arising from formalised conventions of oaths, truces, declarations and challenges. Knights could exploit surprise and guile without setting precedents that undermined the conventions only when their actions violated no specific promises or agreements. And such tactics were 
successful mainly when careless enemies failed to take note of the absence of any such prior agreements ${ }^{12}$ (Strickland 1996, 42-43, 128-31).

Japanese custom lacked all such qualifications. Promises and truces were violated with impunity, as Minamoto Yoritomo demonstrated in his destruction of Satake Yoshimasa, in 1184: Using Taira Hirotsune, a relative of the Satake, as an intermediary, Yoritomo persuaded Yoshimasa to meet him alone, at the centre of a bridge leading to Yoshimasa's home. When Yoshimasa arrived at the meeting point, however, Hirotsune abruptly cut him down, causing many of Yoshimasa's followers to surrender and others to turn and flee (Azuma kagami 1180 11/4).

Medieval audiences considered surprise attacks so utterly normal and fair that an early eleventh-century text begins a description of the archetypical samurai, "the greatest warrior in the land", by informing us that, "he was highly skilled in the conduct of battles, night attacks, archery duels on horseback, and ambushes" (emphasis added) (Shin sarugakki 138).

The foregoing points notwithstanding, we need to guard against censorial judgments of early medieval warriors based on ethnocentric or anachronistic standards for behaviour. Measured against the war conventions of their own time and place, early samurai tactics were no less noble or heroic, and no more treacherous or underhanded, than those of their European contemporaries. Early medieval Japanese rules of engagement demanded that warriors concern themselves only with the most efficient ways to bring about the desired result, with the ends justifying almost any means. The notion that certain sorts of tactics might be "fair" while others were "unfair" was not only inapposite to such deliberations, it was all but extraneous to samurai culture.

\section{Shades of Loyalty}

A second popular theme among modern commentators on bushido concerns the absolute fealty that warriors are alleged to have displayed toward their overlords. Samurai loyalty is described as unconditional and utterly selfless, extending even beyond the deaths of the principals. And indeed, that is the lesson of Chüshingura, Hagakure, and numerous other early modern parables and harangues about samurai values.

12 Brunner $(1992,65)$ notes that, "The Summa legum of Raymond of Wiener Neustadt contended that to kill someone 'without a challenge, without open enmity' (sine diffidacione et sine manifesta inimicitia) was just murder." But Strickland $(1996,128)$ qualifies, "Where no prior agreement was involved, however, surprise and guile might be considered perfectly legitimate. Low cunning was not itself dishonourable; what brought shame was perjury of an oath promising to abstain from such acts." 
But the Tokugawa period was, as we noted earlier, a brave new world, in which on-going peace, shogunal regulations limiting the size of daimyo retainer bands, and fixed tax rates and daimyō incomes rendered the employment market for warriors all but non-existent. Under these circumstances, daimyō could and did demand unqualified loyalty from their retainers. In earlier ages, however, selfless displays of loyalty by warriors are conspicuous in the Japanese historical record mainly by their absence.

From the beginnings of the samurai class and the lord/vassal bond in the tenth century through the end of the "Age of the Country" at War in the late sixteenth, the ties between master and retainer were contractual, based on mutual interest and advantage, and were heavily conditioned by the demands of self-interest. Medieval warriors remained loyal to their lords only so long as it benefited them to do so; they could and did readily switch allegiances when the situation warranted it. In fact there are very few important battles in Japanese history in which the defection-often in the middle of the fighting - of one or more of the major players was not a factor.

Loyalty was, to be sure, also a common trope in shogunal regulations and the house laws formulated by late medieval daimyō. But there are at least two problems involved in interpreting from this that constancy was a fundamental part of medieval warrior character.

To begin with, the idea that subjects owe their rulers unrestricted allegiance is a basic tenet of Confucianism and derives little or nothing from any military tradition per se. Japanese government appeals for loyalty began long before the birth of the samurai-as seen, for example, in the "Seventeen Article Constitution" of Shōtoku Taishi, promulgated in 603. The concept predates even the existence of a Japanese state by hundreds of years, and traces back to the Chinese Confucian philosophers of the sixth to third centuries BCE. Japanese warlords who called upon those that served them to render unflinching loyalty were not so much defining proper samurai behaviour as they were exhorting their subjects on a traditional and general theme of government. Moreover, attempting to deduce norms of actual behaviour from formal legal and moral codes is a treacherous business. Laws and exhortations reflect desired, not actual, behaviour, and attempts of this sort to formulate normative standards often appear in inverse proportion to the prevalence of the behaviour in the real world (Hurst 1990).

The standout feature of warrior alliances in this formative age for the samurai was their fragility. While earlier generations of scholars sometimes drew analogies between warrior networks and the land-commendation process through which 
estates (shōen) were formed, ${ }^{13}$ the two processes were fundamentally different. For, unlike land commendation arrangements, the bonds between warriors were not supported by written contracts. Commendation instruments exist in abundance, but one searches in vain for a single document formalizing a military alliance prior to the agreements issued by Minamoto Yoritomo in the $1180 \mathrm{~s}^{14}$

This absence of legal paperwork regulating early warrior alliances was a reflection of the amorphous nature of the lord-vassal bond during the era. Formal arrangements under which specified benefices were offered in return for defined military services were slow to develop in Japan, because the ability of warrior leaders to manipulate any forms of carrot or stick in order to recruit, maintain or control followers was closely circumscribed by their relatively weak political circumstances until well into the early medieval period. For even the most eminent samurai of the classical age occupied only intermediate positions in the socio-political hierarchy, and were dependent on connections with the higher echelons of the court to maintain their political and economic positions. ${ }^{15}$ Their autonomy in matters of governance and land-holding was limited, which meant that they lacked the right - and therefore the means - to reward or punish their own troops directly.

Warrior allegiances were further circumscribed by the multi-tiered, hierarchical structure of the military networks to which they belonged. Warriors in the organisations of prominent samurai frequently had vassals of their own, and many of these, in turn, had followers. The loyalties of lower-ranking figures in this complex hierarchy to those at the top were tenuous at best, being buffered at each interceding level by the allegiances of their higher-ups.

Nor were ideological constraints of much value in holding early warrior alliances together. Literary war stories like Heike monogatari, which purport to describe events of the early medieval period, are filled with edifying tales attesting to the fierce loyalty displayed by the warriors of the age. And earlier, more reliable sources do give some hints that the fighting men of this time were not entirely oblivious to the concept of fealty as a virtue. But the real effect of this notion on samurai behaviour was minimal. ${ }^{16}$

13 See, for example Yasuda 1962, 12-78.

14 As in the case of patron/client relationships between court nobles, a warrior entering the service of another presented his new master with his name placard (myōbu). There is, however, no evidence that the junior party to the arrangement ever received any written confirmation in exchange. For examples of warriors offering myōbu as gestures of submission, see Heian ibun doc. 2467 or Konjaku monogatarishū 25.9.

15 On this point see Mass 1974, 33-35, 45-54.

16 See, for example, Shōmonki 79, 125-9; Konjaku monogatarishū 25.9; Mutsuwaki 23-24; Chōya gunsai 284 or Chüyūki 1114 5/6. 
Consequently, the integrity of the lord-vassal bond in classical and medieval times tended to be only as strong as the adherents' perceptions that affiliation worked to their advantage. Warrior leaders could count on the services of their followers only to the extent that they were able to offer suitably attractive compensationor, conversely, to impose suitably daunting sanctions for refusal. For the most part, medieval warriors viewed loyalty as a commodity predicated on adequate remuneration, rather than as an obligation transcending self-interest.

In the fourteenth century, expectations concerning commitments and fealty became closely bound up with distinctions between warriors of varying levels of autarky, which, in turn, hardened into hereditary social categories. Thus warriors of means came to be styled tozama ("outsiders"), while those who maintained strong dependent ties to greater lords were called miuchi ("insiders"). Tōzama were ideologically, as well as economically, autonomous. They chose their battles and leaders according to narrowly-defined personal interests and circumstances of the moment, and were more than ready to desert to other employers whenever they thought they might better their situation by doing so. Only warriors without substantial holdings of their own-whose fortunes were therefore inseparable from those of their lords-behaved loyally (Conlan 1997, 42-44).

Nevertheless, the bonds between tozama and their miuchi vassals-and to some extent, the categories themselves-were inherently unstable, inasmuch as they hinged on a disparity of resources that kept the vassals unable to challenge their lords. Much like their Tokugawa period descendants, medieval warriors were reliable only in proportion to their dependence. Those with minimal holdings often displayed striking loyalty to their overlords; those who possessed, or were entrusted with, extensive lands and followers could - and did-condition their service, and compel greater rewards. Beyond a certain point, retainer dependence — and therefore daimyo control—-became nominal. Accordingly, a warrior's military forces grew less and less cohesive as his power and size increased, and his vassals also became landholders of means.

Tozama loyalties and military obligations to those above them were even more fluid and contingent. For while miuchi faithfulness might be demanded as an obligation born of dependency, tozama autonomy in military affairs was normative, and tozama services had to be bought. Presumption of autarky freed tozama from any transcendent duty to fight or serve, shifting the burden of responsibility for maintaining allegiance from the warriors called, to the armies that sought to hire them (Conlan 1997, 46-48).

At the same time, competition for tozama services whittled away at the very authority it manipulated. The existence of rival emperors, each claiming identical — and exclusive - authority, throughout the fourteenth-century Northern and 
Southern Courts (Nanbokuchō) epoch, offered warriors a choice of customers to whom to market their support, and thereby sustained the premise that military services had to be purchased from rightfully autonomous contractors, rather than demanded of obedient subjects or vassals.

The long-term effects were revolutionary: central authority all but ceased to exist other than in name, leading to the fifteenth- and sixteenth-century world of gekokujō ("the low overthrow the high") and jakuniku kyōshoku ("the weak are meat; the strong eat"). The instability of this "Age of the Country at War" eventually inspired the restructuring of daimyo rule, which then led to the early modern polity and changes to the warrior order that I described at beginning of this essay.

$* * *$

To sum up, then: although modern commentators have too often attempted to treat "the way of the warrior" as an enduring code of behaviour readily encapsulated in simplistic notions of honour, duty, and loyalty, the historical reality is anything but simple. Samurai ethics and behavioural norms varied significantly from era to era-most especially across the transition from the medieval to early modern age - and in most cases bore scant resemblance to twentieth-century fantasies about samurai comportment. Even in the early modern period, when bushido became a topic for written pontification, pundits disagreed on the most basic tenets of what it meant to be a proper warrior. Any discussion or exposition of bushido must, therefore, begin with the question, "the way of which warriors?"

\section{References}

Azuma kagami 吾妻鏡/東鑑 (Mirror of the East). 1968. Shintei zōho kokushi taikei. Tokyo: Yoshikawa kōbunkan.

Benesch, Oleg. 2014. Inventing the Way of the Samurai: Nationalism, Internationalism, and Bushido in Modern Japan. Oxford: Oxford University Press. Brunner, Otto. 1992. Land and Lordship: Structures of Governance in Medieval Austria, translated by Howard Kaminsky and James Van Horn. Philadelphia: University of Pennsylvania Press.

Chōya Gunsai 朝野群載総. 1964. Kokushi taikei. Tokyo: Yoshikawa kōbunkan. Chūyūki 中右記. 1965. Zōho shiryō taisei. Kyoto: Rinsen shoten.

Conlan, Thomas. 1997. "Largesse and the Limits of Loyalty in the Fourteenth Century." In The Origins of Japan's Medieval World: Courtiers, Clerics, Warriors, and Peasants in the Fourteenth Century, edited by Jeffrey P. Mass, 39-64. Stanford, CA: Stanford University Press. 
Goseibai Shikimoku 御成敗式目 (Formulary of Adjudications). 1930. In Shinkō gunsho ruijū, edited by Hanawa Hokiichi, 357-5. Tokyo: Meicho Fukyūkai. Heian ibun. 1965. Edited by Takeuchi Rizō, 15 vols. Tokyo: Tōkyōdō.

Hurst, G. Cameron, III. 1990. "Death, Honor, and Loyalty: The Bushidō Ideal." Philosophy East and West 40 (4): 511-27.

Kokon chomonjū 古今著聞集 (A Collection of Notable Tales Old and New). 1983. Shinko Nihon koten shūsei. Edited by Nishio Kōichi and Kobayashi Yasuharu, 2 vols. Tokyo: Shinkosha.

Kokon chomonjū. 1985. Shintei zōho kokushi taikei. Tokyo: Yoshikawa kōbunkan. Konjaku monogatarishū 今昔物語. 1971. Nihon Koten Bungaku Zenshū, vol. 21-24, Tokyo: Shōgakukan.

Mass, Jeffrey P. 1974. Warrior Government in Medieval Japan: A Study of the Kamakura Bakufu, Shugo and Jito. New Haven: Yale University Press.

Mutsuwaki 睦奥話記 (Record of the Deep North). 1941. In Gunsho ruijü (Kassenbu) 22-32. Tokyo: Zoku gunsho ruijū kanseikai.

Nihon kiryaku 日本紀略. 1985. Shintei zōho kokushi taikei. Tokyo: Yoshikawa kōbunkan.

Nitobe Inazō. 1969. Bushido: The Soul of Japan. Tokyo and Rutgers, VT: Tuttle. Sato, Hiroaki. 1995. Legends of the Samurai. Woodstock, NY: Overlook Press.

Shin sarugakki.1986. In Kodai seiji shakai shisō. Nihon shisō taikei. Tokyo: Iwanami shoten.

Shōmonki. 1975. Shinsen Nihon koten bunko. Edited by Hayashi Rokurō, vol. 2. Tokyo: Gendai shichō sha.

Shōyūki 小右記. 1959. Dainihon kokiroku. Tokyo: Iwanami shoten.

Strickland, Matthew. 1996. War \& Chivalry: The Conduct and Perception of War in England and Normandy, 1066-217. New York and London: Cambridge University Press.

Suisaki. 1965. Zōhō shiryō taisei, vol. 12. Kyoto: Rinsen shoten.

Yamamoto, Tsunetomo. 2014. Hagakure: The Secret Wisdom of the Samurai. Translated by Alexander Bennett. Rutledge, VT.: Tuttle.

Yasuda, Motohisa. 1962. "Bushidan no keisei." In Iwanami kōza Nihon rekishi kodai 4: 132-60. Tokyo: Iwanami shoten. 